\title{
Flexural Behaviour of Reinforced Baked Clay Beams
}

\author{
Nawab Ali Lakho, Muhammad Auchar Zardari* \\ Department of Civil Engineering, Quaid-e-Awam University of Engineering, Science and Technology, \\ Nawabshah, Pakistan \\ Email: *muhammad.auchar@quest.edu.pk
}

Received 15 June 2016; accepted 9 July 2016; published 12 July 2016

Copyright @ 2016 by authors and Scientific Research Publishing Inc.

This work is licensed under the Creative Commons Attribution International License (CC BY).

http://creativecommons.org/licenses/by/4.0/

c) (i) Open Access

\begin{abstract}
Construction of Reinforced Cement Concrete (RCC) houses is unaffordable for low income people living in plains of Pakistan because of high cost of cement and aggregates. In such regions, use of Reinforced Baked Clay (RBC) is considered to be a cheaper alternative for RCC. This paper presents structural behaviour of RBC beams. The results of RBC beams were compared with a control RCC beam of same size and reinforcement. Both types of the beams showed similar load deflection behaviour in pre-yield stage. Whereas, in post yield stage, the RBC beams showed comparatively more deflection as compared to the RCC beam. The ultimate load carrying capacity of the RBC beams was almost similar to that of the RCC beam. This study suggests that the RBC beams can be used economically instead of RCC beams without losing strength and safety of a building.
\end{abstract}

\section{Keywords}

\section{Reinforced Baked Clay, Ultimate Load, Deflection, Low Cost, Compressive Strength}

\section{Introduction}

Cost of construction materials of a building i.e. cement, aggregates and steel used in Reinforced Cement Concrete (RCC) is not affordable by low income people of Pakistan. In order to construct buildings at an affordable price, it is necessary to use low cost, long lasting and environment friendly material of construction. In plains of Pakistan, clay is available in huge quantities. When clay is fired, it attains compressive strength as high as normal concrete [1]-[4]. Precast panels of beams and columns can be cast from clay, baked and post-reinforced. These precast panels of Reinforced Baked Clay (RBC) could be used as low cost construction material in place of RCC [5]-[7]. This is because RBC does not require aggregates which are generally transported from distant

\footnotetext{
${ }^{*}$ Corresponding author.
} 
places. In addition, unlike concrete, shrinkage reinforcement is not required if an RBC structural member is strong in compression.

The estimated population of Pakistan in 2015 was 204 million. There is shortage of about 9 million housing units presently in Pakistan. As the population of Pakistan is gradually increasing, this implies that there would be more shortage of houses in future. It is, therefore, necessary to give top priority to this serious problem of scarcity of housing units by using RBC as a cheaper construction material.

Baked clay bricks were utilized in buildings in Asia, Europe and North Africa about 1200 BC [8]. Buildings constructed of baked clay have survived for thousands of years instead of weathering and environmental effects [9]-[11]. With the invention of Ordinary Portland Cement, it became easy to embed reinforcing bars in cement concrete beams to increase their strength in tension zone. Thus, a new age of building construction using RCC started and different building codes were formulated. In this way, the utilization of baked clay was restricted to bricks only.

Load of a building is carried and transferred to supports with the help of beams. Therefore, it is necessary to determine ultimate load carrying capacity and deflection behaviour of a beam. Extensive research has been carried out throughout the world on the use of RCC for more than last 150 years. RBC, as a low cost material of building construction, is a novel approach for construction of affordable houses. In this regard, it is important to investigate load at failure and deflection behaviour of RBC beams and to compare with those of RCC beams. Authors are of the opinion that no such comparative study of RBC and RCC beams is presented in the literature.

\section{Materials and Methods}

\subsection{Casting of Clay Beams}

A mixture of clay and pit sand was prepared. Both the clay and pit sand were obtained locally. Since the clay contained lumps. Therefore, clay was made into powdered form with the help of a Pulverizer (Figure 1). Seventy percentage of powdered clay was mixed with thirty percentage of pit sand by weight. This proportion of clay and pit sand was obtained from a previous study [6]. By using the above mentioned quantity of clay and pit sand, it was observed that clay beams experienced minimum shrinkage and clay cubes gave maximum possible compressive strength. Twenty-two percentage of water was added to the mixture of clay and pit sand. A pan

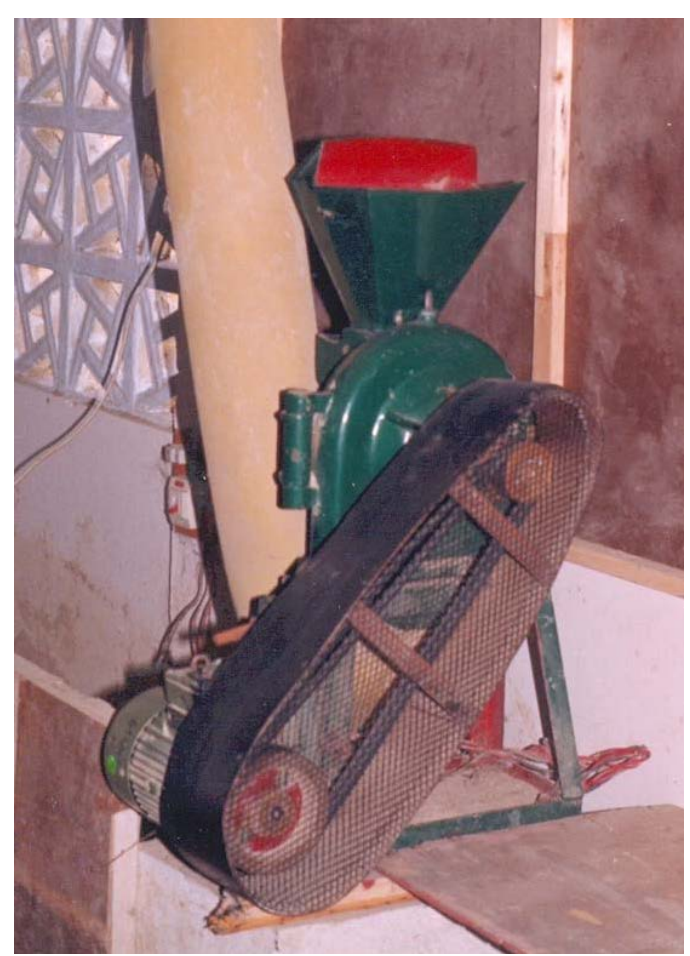

Figure 1. Clay, obtained from the quarry containing lumps, is ground in Pulverizer. 
mixer was used for thorough mixing of the clay, pit sand and water. By using $22 \%$ of water, the mixture of clay and pit sand became workable to cast the beams. Beams of size $150 \mathrm{~mm} \times 300 \mathrm{~mm} \times 1980 \mathrm{~mm}$ were cast in a mould. The beams were pressed with the help of wooden plunger of the Mechanized System (Figure 2). The beams were compacted at a pressure of $6 \mathrm{MPa}$ in the Mechanized System [12]. The beams were then dried in shade. After drying, the beams were fired at a sintering temperature of $1000^{\circ} \mathrm{C}$ in a commercial Hoffman's kiln. The baked clay beams were post-reinforced by inserting two steel bars, each of $12.7 \mathrm{~mm}$ diameter, in perforations that were made during casting. Cross section of a beam and location of reinforcement is shown in Figure 3. The reinforcing bars were welded to anchor plates at both ends of the beams in order to eliminate slip of bars due to weakness of bond between baked clay and steel. Cubes of $150 \mathrm{~mm}$ sides were sawed from the baked clay beams using a cutter machine as shown in Figure 4.

\subsection{Casting of a Concrete Beam and Cubes}

A concrete beam of same size as the RBC beams was also cast. The concrete beam was cured for 28 days. Three concrete cubes of size $150 \mathrm{~mm}$ were also cast and cured for 28 days. The average compressive strength of the concrete cubes was found to be $20 \mathrm{MPa}$. The purpose of the casting and testing of a control concrete beam was to compare the load deflection response and ultimate load carrying capacity with those of RBC beams.

\subsection{Testing Programme}

Both the baked clay and concrete cubes were tested in Forney's Universal Testing Machine (Figure 5). Three white washed RBC beams (Figure 6) and one control RCC beam were tested using Torsee's Beam Testing Machine. The beams were supported on roller supports at the time of testing. Point load was applied at the mid span till the failure of the beams.

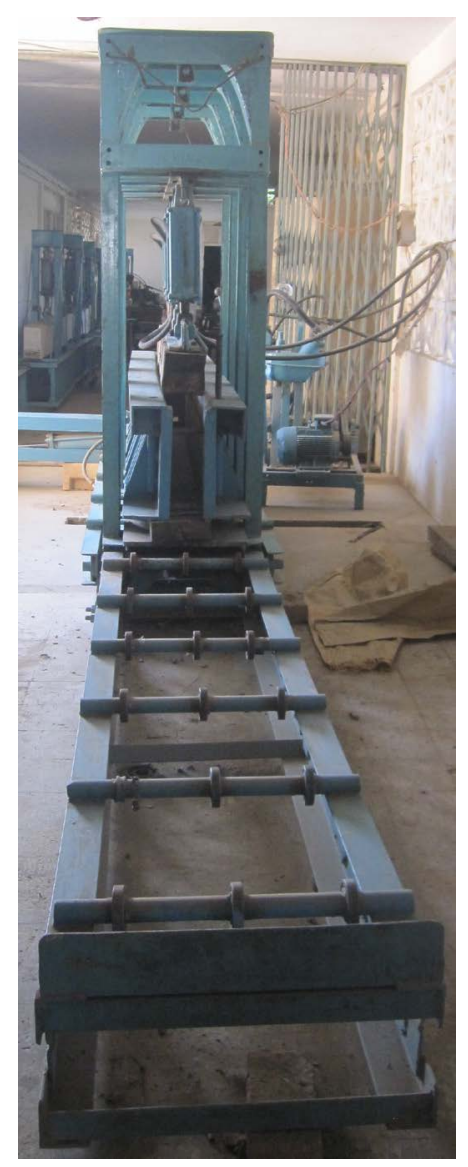

Figure 2. Mechanized system for casting of clay beams. 


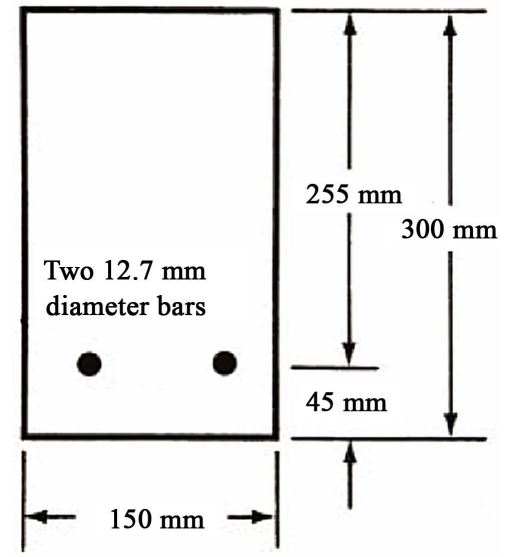

Figure 3. Cross section of reinforced baked clay beam.

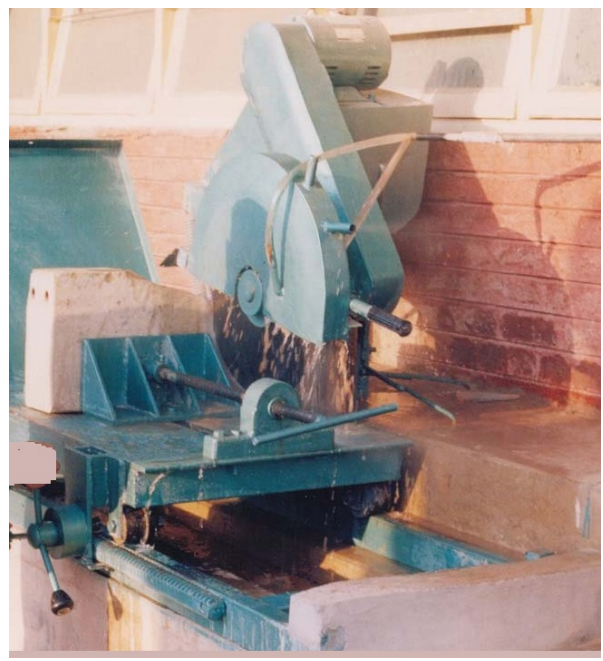

Figure 4. Baked clay cubes of $150 \mathrm{~mm}$ size are sawed using cutter machine.

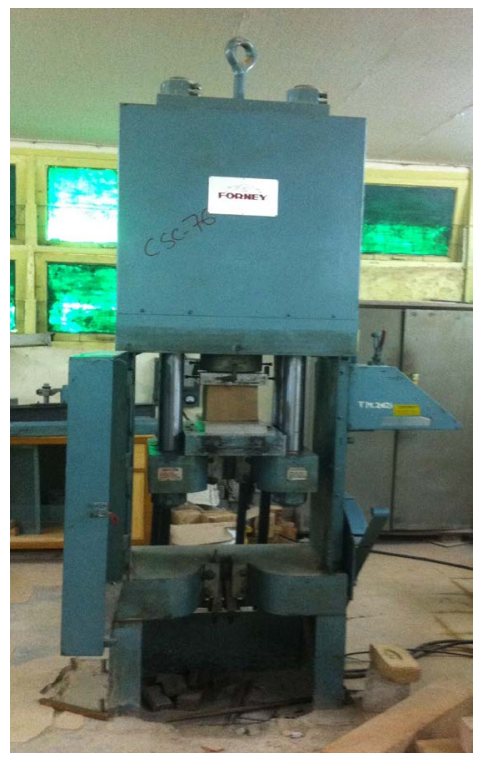

Figure 5. Baked clay cubes of $150 \mathrm{~mm}$ size are being tested in Universal Testing Machine. 


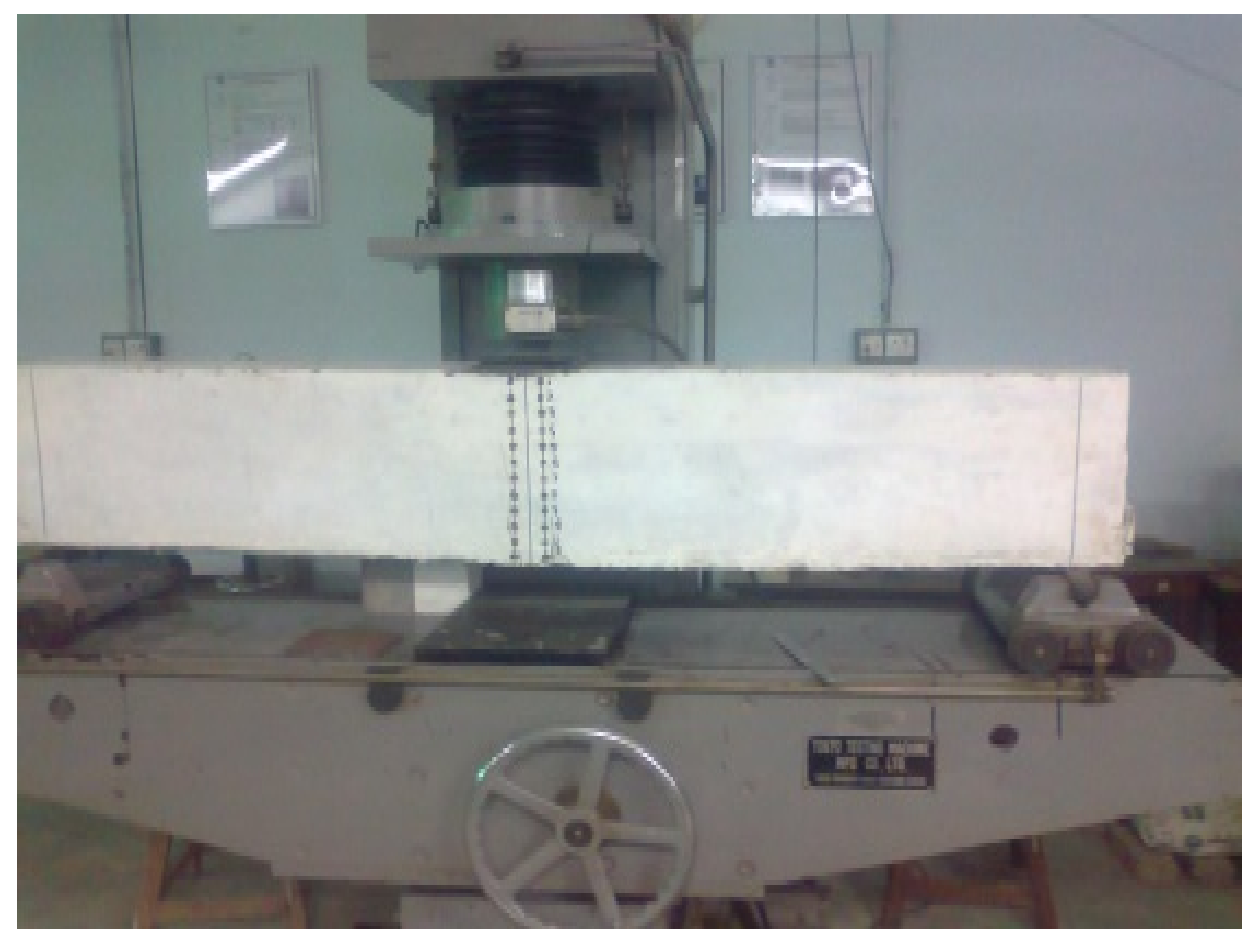

Figure 6. A white washed reinforced baked clay beam is being tested using Torsee’s beam testing machine.

\section{Results and Discussion}

\subsection{Cube Crushing Strength of Baked Clay}

Average cube crushing strength of 5 cubes cut from the baked clay beams was found to be $30 \mathrm{MPa}$ which is about $50 \%$ more than that of normal concrete. It is to be noted that the cube crushing strength of normal concrete is $20 \mathrm{MPa}$ [13]. This implies that compressive strength of baked clay is considered to be satisfactory with reference to normal concrete.

\subsection{Load versus Deflection Response}

It is mentioned earlier that three RBC beams and one control RCC beam were tested to determine deflection behaviour and ultimate load carrying capacity. All the three RBC beams showed similar results for deflection and load at failure. Therefore, for convenience, deflection and ultimate load carried by a representative RBC beam is compared with those of control RCC beam (Figure 7). It can be observed that the RBC beam showed a linear elastic behaviour in deflection and remained un cracked and stiff up to $25 \%$ of the ultimate load. When the intensity of load was increased above $25 \%$ of the ultimate load, cracking of the RBC beam was observed initially at $21 \mathrm{kN}$, which is $26 \%$ of the average ultimate load taken by RBC beams. The RCC beam showed first crack after a load of $20 \mathrm{kN}$ which is similar value at which the crack was observed in RBC beam. The RBC and RCC beams showed ultimate load of magnitude $80 \mathrm{kN}$, and $84 \mathrm{kN}$, respectively. This shows that the ultimate load shown by the RCC beam is only $4 \%$ higher than that of the RBC beams. Both the RBC and the RCC beams showed similar mode of deflection in pre-yield stage. But in post-yield stage, the RBC beams showed more deflection as compared to the RCC beam. This can be attributed to weakness of bond between grouting cement and the smooth internal surface of the perforations that were made in the clay beams at the time of casting. Grouting forms a strong bond with steel bars; but it was observed, after post mortem of the RBC beams, that there was not strong bond between the hardened cement paste and surrounding surface of the perforations in the baked clay beams. When flexural load was applied on the RBC beams, after cracking, this load was transferred to tensile reinforcement and tensile force was applied on full length of the bars. As a result, more elongation in tensile reinforcement of the RBC beams was observed. A detailed study is required to investigate the effect of prestressing in controlling deflection of RBC beams up to the level shown by RCC beams. 


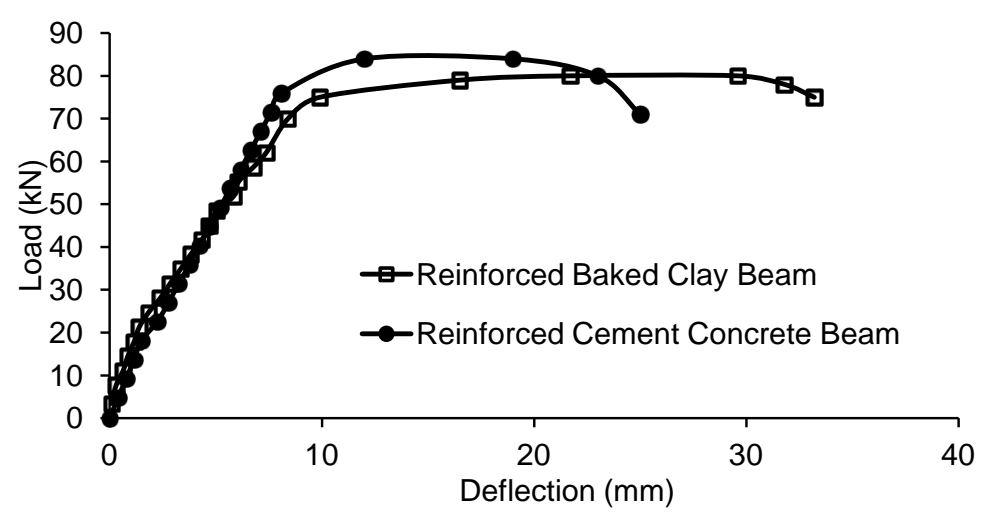

Figure 7. Comparison of load versus deflection response of a reinforced baked clay beam and a reinforced concrete beam.

\section{Conclusions}

Reinforced Baked Clay (RBC) beams were tested in flexure with concentrated load applied at mid span up to complete failure to investigate load deflection behaviour and ultimate load carrying capacity. The results were compared with a control Reinforced Cement Concrete (RCC) beam of same size and reinforcement. Following conclusions were drawn from this study:

1) Average cube crushing strength of standard size cubes sawed from the baked clay beams was observed to be $30 \mathrm{MPa}$. This value of the compressive strength of the baked clay is about $50 \%$ more than that of normal concrete.

2) Both the RBC and the RCC beams showed similar load deflection behaviour in pre-yield stage.

3) In post yield stage, the RBC beams showed comparatively more deflection as compared to the RCC beam.

4) The ultimate load carrying capacity of the RBC beams was about $4 \%$ lower as compared to the control RCC beam. This is not a significant difference of the ultimate load carried by both types of beams. This implies that the RBC beams could be used as a low cost alternative material in place of RCC beams for construction of a building.

5) It is suggested to reduce the rate of deflection in RBC beams using prestressing techniques.

\section{Acknowledgements}

The authors would like to thank Quaid-e-Awam University of Engineering, Science and Technology Nawabshah, for providing access to the Structural Engineering Laboratory to conduct the tests mentioned in this study.

\section{References}

[1] Karaman, S., Ersahin, S. and Gunal, H. (2006) Firing Temperature and Firing Time Influence on Mechanical and Physical Properties of Clay Bricks. Journal of Scientific and Industrial Research, 65, 153-159.

[2] Karaman, S., Gunal, H. and Ersahin, S. (2006) Assesment of Clay Bricks Compressive Strength Using Quantitative Values of Colour Components. Construction and Building Materials, 20, 348-354. http://dx.doi.org/10.1016/j.conbuildmat.2004.11.003

[3] Johari, I., Said, S., Hisham, B., Bakar, A. and Ahmad, Z.A. (2010) Effect of the Change of Firing Temperature on Microstructure and Physical Properties of Clay Bricks from Beruas (Malaysia). Science of Sintering, 42, 245-254. http://dx.doi.org/10.2298/SOS1002245J

[4] Ansari, A.A., Bhatti, N.K. and Bhutto, A. (2013) Suitability of Pre-Perforated Post-Reinforced Baked Clay Beam Panels for Low Cost Housing. American Journal of Civil Engineering, 1, 6-15. http://dx.doi.org/10.11648/j.ajce.20130101.12

[5] Ansari, A.A. and Lakho, N.A. (2013) Determination of Structural Properties of Baked Clay as Replacement of RCC. International Journal of Emerging Technology and Advanced Engineering, 3, 17-25.

[6] Ansari, A.A. (2008) Experimental Study of the Behaviour of Pre-Perforated Post-Reinforced Baked Clay Panels of Beams. Ph.D. Thesis, Quaid-e-Awam University of Engineering Science and Technology, Nawabshah. 
[7] Lakho, N.A. and Zardari, M.A. (2016) Comparison of Compressive and Tensile Strength of Baked Clay with Those of Normal Concrete. Engineering, 8, 301-307. http://dx.doi.org/10.4236/eng.2016.86027

[8] Campbell, J.W. (2003) Brick: A World History. Thames \& Hudson, London.

[9] López-Arce, P., Garcia-Guinea, J., Gracia, M. and Obis, J. (2003) Bricks in Historical Buildings of Toledo City: Characterisation and Restoration. Materials Characterization, 50, 59-68. http://dx.doi.org/10.1016/S1044-5803(03)00101-3

[10] Özkaya, Ö.A. and Böke, H. (2009) Properties of Roman Bricks and Mortars Used in Serapis Temple in the City of Pergamon. Materials Characterization, 60, 995-1000. http://dx.doi.org/10.1016/j.matchar.2009.04.003

[11] Minke, G. (2012) Building with Earth: Design and Technology of a Sustainable Architecture. Birkhäuse, Boston.

[12] Lakho, N.A, Zardari, M.A., Memon, M. and Saand, A. (2015) Design and Fabrication of Mechanized System for Casting and Compacting Laboratory Size Clay Beams. Scientia Iranica, 22, 2046-2051.

[13] BS EN 12390-3 (2009) Testing Hardened Concrete-Part 3: Compressive Strength of Test Specimens. Management Centre: Avenue Marnix 17, B-1000 Brussels.

\section{Submit or recommend next manuscript to SCIRP and we will provide best service for you:}

Accepting pre-submission inquiries through Email, Facebook, Linkedin, Twitter, etc A wide selection of journals (inclusive of 9 subjects, more than 200 journals)

Providing a 24-hour high-quality service

User-friendly online submission system

Fair and swift peer-review system

Efficient typesetting and proofreading procedure

Display of the result of downloads and visits, as well as the number of cited articles

Maximum dissemination of your research work

Submit your manuscript at: http://papersubmission.scirp.org/ 